\title{
PERBEDAAN TINGKAT KESEGARAN JASMANI ANTARA SISWA PESISIR DENGAN SISWA PEGUNUNGAN PADA SD NEGERI 46 KOTA PAREPARE
}

\author{
Joni Muis \\ Prodi PGSD Fakultas Ilmu Pendidikan Universitas Negeri Makassar \\ Joni_muis@yahoo.co.id
}

\begin{abstract}
ABSTRAK
Penelitian ini bertujuan untuk mengetahui apakah terdapat perbedaan tingkat kesegaran jasmani antara siswa yang tinggal di pesisir dengan siswa yang tinggal di pegunungan di SDN 46 Kota Parepare. Penelitian ini menggunakan metode studi komperatif, penelitian deskriptif ini yang ingin mencari jawab secara mendasar tentang sebab-akibat, dengan menganalisis factor-faktor penyebab terjadinnya atau munculnya suatu fenomena tertentu tentang kemampuan tingkat kesegaran jasmani siswa dengan membedakan unsur geografis siswa antara daerah pesisir dan pegunungan. Populasi adalah keseluruhan siswa putra SD kelas IV dan kelas V SDN 46 Kota Parepare, Sampel dalam penelitian ini adalah siswa yang tinggal di daerah pesisir dan pegunungan dengan jumlah 30 orang siswa kelas IV dan kelas V laki-laki, 15 siswa yang tinggal di daerah pesisir dan 15 siswa yang tinggal di daerah pegunungan. Teknik pengambilan sampel dengan cara purposive sampling. Dari data penelitian menunjukkan bahwa tingkat kesegaran jasmani siswa yang tinggal di daerah pegunungan mempunyai tingkat kesegaran jasmani yang lebih baik dibandingkan tingkat kesegaran jasmani siswa yang tinggal di daerah pesisir
\end{abstract}

Kata kunci : Kesegaran Jasmani, daerah pesisir, pegunungan

\section{PENDAHULUAN}

Tujuan pendidikan nasional adalah mencerdaskan kehidupan bangsa dan membangun manusia indonesia seutuhnya, yaitu manusia yang beriman, bertaqwa kepada Tuhan Yang Maha Esa, berbudi pekerti yang luhur, memiliki pengetahuan dan keterampilan, kesehatan jasmani dan rohani, kepribadian yang mantap dan mandiri serta memiliki rasa tanggung jawab pada bangsa dan negara.

Untuk mencapai tujuan tersebut maka pendidikan nasional harus diselenggarakan secara terpadu dan diarahkan pada peningkatan kualitas serta pemerataan pendidikan, terutama peningkatan kualitas pendidikan dasar yang merupakan awal dari pembentukan manusia indonesia seutuhnya guna dapat memenuhi kebutuhan pembangunan nasional.

Sekolah dasar merupakan salah satu jenjang pendidikan formal sebagai tempat yang sagat baik untuk mendidik anak atau dengan kata lain potensi-potensi atau bakat-bakat yang dimiliki anak dibina dan diarahkan melalui pendidikan dasar sehingga pada jenjang pendidikan selanjutnya dapat lebih ditingkatkan.

Siswa sekolah dasar merupakan individu yang sedang mengalami pertumbuhan dan perkembangan fisik yang sangat pesat, sekaligus sebagai mahluk sosial yang mempunyai sifat ketergantungan dengan orang lain yang ada di sekelilingnya untuk, mendapatkan bantuan, arahan serta bimbingan ke arah kesegaran jasmani dan perkembangannya. Oleh karena itu, perlu mendapatkan perhatian khusus dari orang tua dan guru maupun dari masyarakat dan pemerintah. Dengan dasar tersebut maka salah satu upaya yang dilakukan untuk meransang peningkatan kesegaran jasmani dan perkembangan fisik anak yakni dengan menempuh jalur pendidikan olahraga. Dengan melakukan olahraga secara teratur dan sistematis maka otot akan menjadi kuat dan berkembang serta membuat organ-organ tubuh berfungsi dengan baik. Sebagaimana dikemukakan oleh Dede Kusuma (1989:5) : "Olahraga adalah segala kegiatan untuk mendorong, membangkitkan, mengembangkan dan membina kekuatan jasmani maupun rohani pada setiap manusia yang dalam pengertian sempit adalah gerak badan untuk menguatkan badan, menyehatkan jasmani dan rohani".

Dunia pendidikan olahraga merupakan suatu pelajaran yang sangat penting untuk membangun jiwa, fisik dan mental anak dalam pencapaian kesegaran jasmani yang baik. Dimana kesegaran jasmani merupakan hal yang sangat penting untuk dimiliki setiap 
individu karena dapat menunjang kelancaran aktivitas yang dilakukan sehari-hari tanpa mengalami kelelahan yang berarti dan masih memiliki tenaga cadangan untuk melaksanakan kegiatan yang lain. Dengan demikian siswa vang mempunyai kesegaran jasmani vang baik akan dapat mengikuti pelajaran dalam situasi yang menyenangkan, sehat dan tampak lebih bugar penampilannya dalam melakukan kegiatan belajar dengan hasil yang baik dan memuaskan.

Oleh sebab itu dapat dikatakan bahwa kesegaran jasmani merupakan modal dasar yang mendukung pembangunan nasional, karena dengan derajat kesehatan dan kesegaran jasmani yang prima yang dimiliki oleh setiap individu akan mampu bekerja dengan baik dan tahan terhadap kelelahan. Dengan demikian kesegaran jasmani merupakan kunci dari keberhasilan dalam kehidupan sehari-hari, demikian pula halnya bagi siswa, yakni berperan untuk meningkatkan kemampuan belajar sehingga memungkinkan untuk dapat mencapai hasil belajar yang baik.

Tingkat perkembangan fisik manusia berbeda-beda, begitu pula kesegaran jasmaninya, walaupun berada pada tingkat usia yang sama. Supartina Pakasi (1981:28) mengatakan bahwa "tidak ada dua orang yang sama benar, sekalipun mereka itu anak kembar yang lahir dari satu buah telur". Perbedaan tersebut diduga disebabkan karena antara lain : jenis kelamin, usia, jenis pekerjaan, lingkungan, iklim, emosi, makanan dan lainlain.

Lingkungan dimana anak tersebut berada sangat mempengaruhi kemampuan jasmaninya. Seperti halnya siswa di SDN 46Kota Parepare yang memiliki dua keadaan lingkungan yang berbeda, yaitu siswa yang tinggal di daerah pegunungan dan siswa yang tinggal di daerah pesisir. Apabila ditinjau secara umum, maka dapat dikatakan bahwa kemampuan jasmani siswa SDN 46 Kota Parepare cukup baik, karena faktor yang mendukung kearah tersebut cukup memadai. Seperti halnya sarana kesehatan, perekonomian, rekreasi dan sarana olahraga, sehingga anak akan melakukan olahraga yang mereka inginkan. Akan tetapi dengan adanya dua keadaan lingkungan yang berbeda yakni lingkungan pesisir dan lingkungan pegunungan menyebabkan aktifitas fisik yang dilakukan juga berlainan.

Daerah pesisir memiliki sarana olahraga yang mencukupi, sehingga motivasi untuk berolahraga akan meningkat. Di samping itu keadaan ekonomi yang mendukung sehingga memberikan nilai gizi yang baik, apalagi ditunjang oleh tingkat pendidikan orang tua yang memadai, serta tersedianya sarana rekreasi yang mampu memberikan kesegaran mental bagi anak. Kesemuanya itu akan merupakan pemicu bagi perkembangan kemampuan jasmani anak dalam hal ini kesegaran jasmaninya maupun kemampuan berolahraganya.

Berbeda halnya bagi anak yang berada di lingkungan pegunungan dimana keadaan ekonomi dan pengetahuan masalah gizi masih rendah dari masyarakat daerah pesisir sehingga diduga kemampuan fisiknya lebih rendah dibanding dengan anak pesisir. Di samping itu sarana olahraga yang masih terbatas di pegunungan mempengaruhi kegemaran anak dalam berolahraga. Namun ditinjau dari segi lain, yakni keadaan lingkungan yang memaksa mereka untuk banyak mengaktifkan fisiknya, seperti membantu orang tua untuk bekerja, serta didukung dengan keadaan alam yang sehat dan udara yang masih segar. Keadaan lingkungan yang demikian juga turut mempengaruhi tingkat kesegaran jasmaninya.

Uraian di atas nampak adanya perbedaan karakteristik antara lingkungan pesisir dengan lingkungan pegunungan pada siswa SDN 46 Kota Parepare. Adanya perbedaan tersebut sehingga diduga dapat mengakibatkan tingkat kesegaran jasmani dan kemampuan berolahraga anak akan berbeda pula.

Hal-hal yang dikemukakan di atas merupakan dasar pemikiran penulis yang dikembangkan berdasarkan karakteristikkarakteristik yang membedakan antara anak yang tinggal di pesisir dengan anak yank tinggal di pegunungan. Atas dasar pemikiran tersebut sehingga penulis bermaksud untuk mengetahui secara pasti melalui prosedur ilmiah dengan judul : perbandingan tingkat Kesegaran Jasmani Antara Siswa yang Tinggal di Pesisir dengan Siswa yang Tinggal di Pegunungan di SDN 46 Kota Parepare.

\section{Hakikat Kesegaran Jasmani}

Kesegaran jasmani memiliki peran penting dalam kegiatan sehari-sehari. Pentingnya kesegaran jasmani telah melahirkan slogan bahwa kesegaran jasmani yang baik dari suatu bangsa dapat meningkatkan karakter suatu bangsa. Kesegaran jasmani yang tinggi diperlukan oleh semua orang termasuk anaka usia sekolah mulai Taman kanak-kanak (TK) 
sampai sekolah lanjutan tingkat atas (SLTA). Dengan memiliki kesegaran jasmani yang tinggi, siswa mampu melakukan aktivitas sehari-hari dengan waktu lebih lama dibanding siswa yang memiliki tingkat kesegaran jasmani rendah.

Pentingnya kesegaran jasmani bagi anak usia sekolah antara lain dapat meningkatkan kemampuan organ tubuh, sosial emosional, sportivitas. Dan semangat kompetisi . Beberapa penelitian juga menyebutkan bahwa kesegaran jasmani memilki korelasi positif dengan prestasi akademis. Dari sudut pandang pendidikan upaya peningkatan kesegaran jasmani memiliki tujuan antara lain : (1) Pembentukan gerak, (2) Pembentukan prestasi, (3) Pembentukan sosial, dan (4) Pertumbuhan badan.

\section{Pengertian Kesegaran Jasmani}

Kesegaran jasmani atau dalam istilah bahasa asing disebut "physical fitness", yang kalau diartikan menurut asal katanya berarti. badan yang sehat dan bugar. Dengan kata lain secara sederhana dapat diartikan sebagai suatu kondisi dimana manusia merasa sehat, segar bugar secara fisik dan secara psikis (mental).

Pengertian tentang kesegaran. jasmani yang dikemukakan oleh para ahli berbeda-beds, apalagi bila dikaji dari bidang studi dan sudut pandang yang berbeda. M. Anwar Pasau (1984:89) mengutip pendapat beberapa ahli yang terbagi dalam tiga kelompok sudut pandang dalam pengertian kesegaran jasmani :

1. Kelompok dari ahli/Dokter kesehatan, kesegaran jasmani dirumuskan sebagai kemampuan pemulihan (recovery) pernafasan dan peredarah darah sesudah melakukan pekerjaan atau tugas gerak tertentu (Anderson 1961). Suatu pernyataan bahwa sistem dalam tubuh dalam keadaan mampu/siap untuk memikul kegiatan-kegiatannya secara memuaskan (Bortz, 1961). Kesegaran jasmani tergantung pads potensi fungsional dan metabolisms (Balks 1960).

2. Pengertian dari sudut pandang para. ahli fisiologis, mengemukakan bahwa kesegaran jasmani merupakan suatu pernyataan kuantitatif dan kondisi fisik seseorang. Suatu kemampuan untuk memikul tugas spesifik yang membutuhkan usaha perototan dimana kecepatan dan daya tahan merupakan kriteria utama. (Consolazio, Johnson, Pecosa. 1963)

3. Pengertian dari sudut pandang para ahli olahraga, kesegaran jasmani adalah kemampuan individu untuk mengembangkan suatu tugas atau menyelesaikan suatu tugas sampai selesai dengan baik tanpa mengalami kelelahan yang berarti (Browel dan Hogman 1951).

Berdasarkan pengertian kesegaran jasmani yang dikemukakan oleh para ahli di atas, meskipun ada perbedaan dalam menjabarkannya, akan tetapi nampak bahwa maksud dan tujuannnya adalah sama yang memberikan gambaran sebagai kemampuan dasar fisik atau kondisi fisik untuk melakukan beban kerja tanpa mengalami kelelahan yang berlebihan setelah menyelesaikan beban tugas secara fisik.untuk itu: dapat pula dikatakan bahwa kesegaran jasmani merupakan persyaratan kualitas dari kondisi fisik seseorang atau suatu kemampuan untuk memikul beban tugas tanpa mengalami kelelahan yang berkepanjangan. Tugas dan beban fisik misalnya adalah tugas secara spesifik dalam bentuk keterampilan olahraga maupun tugas lainnya yang memerlukan usaha perototan, kemampuan jantung untuk memompa darah dan menghirup oksigen dalam jumlah yang banyak atau kesegaran cardiovaskuler.

\section{Konsep Lingkungan}

Lingkungan merupakan faktor yang dapat mempengaruhi tingkat pertumbuhan fisik seseorang. Dan yang paling memegang peranan di sini adalah keadaan ekonomi yang berhubungan dengan keadaan gizi, lingkungan sosialnya, aktivitas yang dilakukan sehari-hari, sarana dan prasarana olahraga, jugs pola pikir masyarakat.

Menurut Siallo (1986) yang dikutif oleh Lisnawati (1996:21) menjelaskan bahwa "lingkungan ialah segala benda, kondisi, keadaan dan pengaruh yang terdapat dalam ruang yang kita tempati dan mempengaruhi segala hal yang hidup termasuk kehidupan manusia".

Dari definisi di atas dapat dikemukakan bahwa lingkungan mempengaruhi segala kehidupan dan aktivitas manusia. Lingkungan mempengaruhi pertumbuhan fisik maupun kemampuan jasmani seseorang dimana mereka tinggal, apakah tinggal di daerah pesisir atau tinggal di daerah pegunungan. Jadi jelaslah bahwa lingkungan berpengaruh terhadap tingkat pertumbuhan fisik seseorang. Hal ini disebabkan karena keadaan lingkungan yang berbeda dan dari faktor lainnya seperti keadaan gizi, keadaan ekonomi dan pola pikir 
masyarakat maupun sarana dan prasarana yang tersedia, termasuk sarana dan prasarana olahraga.

\section{METODE PENELITIAN}

Dalam penelitian ini, metode yang digunakan adalah metode survei. Metodelogi dalam suatu penelitian harus tepat dan sesuai dengan tujuan serta dapat di pertanggung jawabkan kebenarannya secara ilmiah. Metodologi penelitian sebagaimana kita kenal memberikan garis-garis yang sangat cermat dan mengajukan syarat-syarat keras. Maksudnya adalah untuk menjaga agar pengetahuan yang dicapai dari suatu penelitian dapat mempunyai harga ilmiah setinggitingginya (Hadi, 1990:24).

\section{Rancangan Penelitian}

Penelitian komperatif adalah sejenis penelitian deskriptif yang ingin mencari jawab secara mendasar tentang sebab-akibat, dengan menganalisis factor-faktor penyebab terjadinnya atau munculnya suatu fenomena tertentu. Jangakauan waktu adalah masa sekarang, karena jika jangkauan waktu terjadinya adalah masa lampau, maka penelitian tersebut termasuk dalam metode sejarah. Dalam studi komperatif ini, memeng sulit untuk mengetahui factor-faktor penyebab yang dijadikan dasar pembanding, seperti penelitain komperatif tidak mempunyai control. Hal ini semakin nyata kesulitannya jika kemungkinan-kemungkinan hubungan antar fenomena banyak sekali jumlahnya

Studi komperatif banyak sekali dilakukan jika metode eksperimental tidak dapat diperlukan. Bidang studi mencakup penghiduupan kota dan desa, dengan membandingkan pengaruh sebab akibat dari makanan, rekreasi, waktu kerja, ketenangan kerja, dan sebagainnya. Penelitian komperatif dilakukan untuk mencari pola tingkah laku serta kemampuan tingkat kesegaran jasmani siswa dengan membedakan unsur geografis siswa antara daerah pesisir dan pegunungan. Secara sederhana desain penelitian digambarkan.

\begin{tabular}{ccc}
\hline $\begin{array}{c}\text { Variabel } \\
\text { Penelitian }\end{array}$ & $\mathrm{X}$ & $\mathrm{Y}$ \\
\hline $\mathrm{A}$ & $\mathrm{AX}$ & $\mathrm{AY}$ \\
\hline
\end{tabular}

Gambar 1. Rancangan Penelitian

Keteragan:
$\mathrm{X}=$ siswa yang tinggal di pegunungan

$\mathrm{Y}=$ siswa yang tinggal di pesisir

$\mathrm{A}=$ Tingkat kesegaran jasmani siswa

Populasi adalah keseluruhan subyek penelitian (Arikunto, 1991:102), adapun yang menjadi subyek dalam penelitian ini adalah siswa putra SD kelas IV dan kelas V SDN 46 Kota Parepare.

Sekolah yang dijadikan sebagai obyek penelitian tersebut dipilih secara sengaja oleh karena pertimbangan sebagai berikut:

a. Sekolah tersebut dapat menyediakan segala fasilitas yang diperlukan selama penelitian.

b. Adanya dukungan dari kepala sekolah untuk memberikan kesempatan dalam pengambilan data-data yang diperlukan.

c. Sekolah tersebut tempat mengajar peneliti sehingga memungkin pengambilan data di lapangan dapat berjalan lancar.

Sampel dalam penelitian ini adalah siswa yang tinggal di daerah pesisir dan siswa yang tinggal di daerah pegunungan dengan jumlah 30 orang siswa kelas IV dan kelas $\mathrm{V}$ laki-laki, 15 siswa yang tinggal di daerah pesisir dan 15 siswa yang tinggal di daerah pegunungan. Teknik pengambilan sampel dengan cara purposive sampling. Teknik ini berdasarkan pada ciri-ciri atau sifat-sifat tertentu yang diperkirakan mempunyai sangkut paut erat dengan ciri-ciri atau sifat-sifat tertentu yang ada dalam populasi yang sudah diketahui sebelumnya. (Narbuko:116)

\section{Instrumen Penelitian}

Instrumen yang digunakan dalam penelitian ini adalah Tes Kesegaran Jasmani Indonesia (TKJI) untuk putra (10-12) yang meliputi:
a. lari 40 meter
b. gantung angkat tubuh (pull up)
c. baring duduk (sit up) selama 30 detik
d. loncat tegak (vertical jump)
e. lari 600 meter

\section{Teknik Pengumpulan Data}

Teknik pengumpulan data adalah merupakan syarat mutlak dalam melakukan suatu kerja ilmiah. Teknik pengumpulan data dalam penelitian ini meliputi tes kesegaran iasmani yang terdiri dari : tes lari cepat 50 meter,tes bergantung siku tekuk, tes baring duduk, tes lompat tegak, dan tes lari jarak 600 meter. (tes Kesegaran Jasmani Indonesia, Jakarta 2000) 
Adapun teknik analisis data yang digunakan dalam penelitian ini adalah statistik deskriptif dengan prosentase.

$$
\mathrm{P}=\frac{\mathrm{f}}{\mathrm{N}} 100 \%
$$

(Anas Sudijino, 2005:43)

Keterangan :

$\mathrm{P}=$ Angka Persentasr

$\mathrm{f}=$ Skor / nilai yang diperoleh oleh siswa

$\mathrm{N}=$ Jumlah siswa/sampel.

Artinya bahwa dengan hasil data yang diperoleh dari penelitian ini akan menggambarkan keadaan kesegaran jasmani yang diteliti, kemudian berdasarkan data tersebut akan mendapat gambaran tentang tingkat kesegaran jasmani siswa yang tinggal di pegunungan dengan siswa yang tinggal di pesisir.

\section{HASIL \& PEMBAHASAN}

Untuk mengetahui gambaran tingkat kesegaran jasmani siswa yang tinggal di pegunungan dan siswa yang tinggal di pesisir dilihat dari hasil tes kesegaran jasmani yang terdiri dari 5 bagian yaitu lari 40 meter, gantung siku teku, baring duduk 30 detik, loncat tegak, dan lari 600 meter.

Tabel 1. Hasil Tes Tingkat Kesegaran Jasmani Siswa yang Tinggal di daerah Pegunungan

\begin{tabular}{|c|c|c|c|c|c|c|}
\hline No & Responden & $\begin{array}{l}\text { Lari } 40 \\
\text { Meter }\end{array}$ & $\begin{array}{c}\text { Gantung } \\
\text { Siku Tekuk }\end{array}$ & $\begin{array}{l}\text { Baring } \\
\text { Duduk }\end{array}$ & $\begin{array}{l}\text { Loncat } \\
\text { Tegak }\end{array}$ & $\begin{array}{c}\text { Lari } 600 \\
\text { Meter }\end{array}$ \\
\hline 1 & $\mathrm{R} 1$ & $6,5^{\prime \prime}$ & $10 "$ & 20 & 35 & $2,48^{\prime \prime}$ \\
\hline 2 & $\mathrm{R} 2$ & $6,5^{\prime \prime}$ & 4" & 15 & 25 & $2,40^{\prime \prime}$ \\
\hline 3 & R3 & $6,7^{\prime \prime}$ & $25^{\prime \prime}$ & 20 & 33 & $2,25^{\prime \prime}$ \\
\hline 4 & $\mathrm{R} 4$ & $7,5^{\prime \prime}$ & $45^{\prime \prime}$ & 20 & 40 & $2,40 "$ \\
\hline 5 & $\mathrm{R} 5$ & 7,5 " & $30 "$ & 13 & 25 & $2,20^{\prime \prime}$ \\
\hline 6 & R6 & $6,4 "$ & $23 "$ & 22 & 35 & $2,22 "$ \\
\hline 7 & R7 & $6,8^{\prime \prime}$ & $45^{\prime \prime}$ & 25 & 48 & $2,08^{\prime \prime}$ \\
\hline 8 & $\mathrm{R} 8$ & $7,0 "$ & $48 "$ & 13 & 28 & $2,20 "$ \\
\hline 9 & R9 & $6,8^{\prime \prime}$ & $25 "$ & 25 & 27 & $2,15^{\prime \prime}$ \\
\hline 10 & R10 & $6.5 "$ & $23 "$ & 20 & 35 & $2,20 "$ \\
\hline 11 & R11 & $6,7 "$ & $27 "$ & 24 & 25 & $2,22^{\prime \prime}$ \\
\hline 12 & R12 & $6,5^{\prime \prime}$ & $30 "$ & 20 & 35 & $2,20 "$ \\
\hline 13 & R13 & $6,5^{\prime \prime}$ & $30 "$ & 26 & 27 & $2,15^{\prime \prime}$ \\
\hline 14 & R14 & $6.5^{\prime \prime}$ & $23 "$ & 25 & 28 & $2,20 "$ \\
\hline 15 & R15 & $6,7^{\prime \prime}$ & $27 "$ & 20 & 33 & $2,22^{\prime \prime}$ \\
\hline
\end{tabular}

Tabel 2. Norma Hasil Tes Tingkat Kesegaran Jasmani Siswa yang Tinggal di daerah Pegunungan

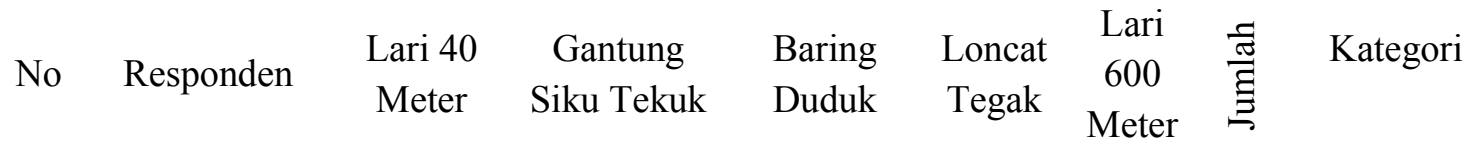

\begin{tabular}{lllllllll}
\hline 1 & R1 & 4 & 2 & 4 & 3 & 2 & 15 & Sedang \\
\hline 2 & R2 & 4 & 1 & 3 & 2 & 3 & 13 & Kurang \\
\hline 3 & R3 & 4 & 3 & 4 & 3 & 4 & 18 & Baik \\
\hline 4 & R4 & 3 & 4 & 4 & 4 & 3 & 18 & Baik \\
\hline 5 & R5 & 3 & 3 & 3 & 2 & 4 & 15 & Sedang \\
\hline 6 & R6 & 4 & 3 & 4 & 3 & 4 & 18 & Baik \\
\hline 7 & R7 & 4 & 4 & 5 & 5 & 5 & 23 & Baik sekali \\
\hline 8 & R8 & 3 & 4 & 3 & 2 & 4 & 16 & Sedang \\
\hline 9 & R9 & 4 & 3 & 5 & 2 & 4 & 18 & Baik \\
\hline 10 & R10 & 4 & 3 & 4 & 3 & 4 & 18 & Baik \\
\hline
\end{tabular}




\begin{tabular}{lllllllll}
\hline 11 & R11 & 4 & 3 & 5 & 2 & 4 & 18 & Baik \\
\hline 12 & R12 & 4 & 3 & 4 & 3 & 4 & 18 & Baik \\
\hline 13 & R13 & 4 & 3 & 5 & 2 & 4 & 18 & Baik \\
\hline 14 & R14 & 4 & 3 & 5 & 2 & 4 & 18 & Baik \\
\hline 15 & R15 & 4 & 3 & 4 & 3 & 4 & 18 & Baik \\
\hline
\end{tabular}

Tabel 3 Hasil Tes Tingkat Kesegaran Jasmani Siswa yang Tinggal di Daerah Pesisir

\begin{tabular}{|c|c|c|c|c|c|c|}
\hline No & Responden & $\begin{array}{c}\text { Lari } 40 \\
\text { Meter }\end{array}$ & $\begin{array}{c}\text { Gantung } \\
\text { Siku } \\
\text { Tekuk }\end{array}$ & $\begin{array}{l}\text { Baring } \\
\text { Duduk }\end{array}$ & $\begin{array}{c}\text { Loncat } \\
\text { Tegak }\end{array}$ & $\begin{array}{c}\text { Lari } 600 \\
\text { Meter }\end{array}$ \\
\hline 1 & R16 & $6,5^{\prime \prime}$ & $12 "$ & 18 & 33 & $2,40^{\prime \prime}$ \\
\hline 2 & R17 & $6.5^{\prime \prime}$ & $23^{\prime \prime}$ & 19 & 35 & 2,32 \\
\hline 3 & R18 & $6,7^{\prime \prime}$ & $27^{\prime \prime}$ & 20 & 25 & 2,15 \\
\hline 4 & R19 & $7,7^{\prime \prime}$ & $32 "$ & 20 & 40 & $2,33^{\prime \prime}$ \\
\hline 5 & R20 & $7,5^{\prime \prime}$ & $27^{\prime \prime}$ & 13 & 24 & $2,22^{\prime \prime}$ \\
\hline 6 & R21 & $6,6 "$ & $20 "$ & 21 & 25 & $2,20 "$ \\
\hline 7 & R22 & $6.5^{\prime \prime}$ & $20 "$ & 25 & 25 & $2,15^{\prime \prime}$ \\
\hline 8 & R23 & $7,2^{\prime \prime}$ & $33 "$ & 15 & 27 & $2,20 "$ \\
\hline 9 & R24 & $6,4^{\prime \prime}$ & $4 "$ & 15 & 24 & $2,35^{\prime \prime}$ \\
\hline 10 & $\mathrm{R} 25$ & $7,4^{\prime \prime}$ & $23 "$ & 12 & 25 & $2,20 "$ \\
\hline 11 & R26 & $6,5^{\prime \prime}$ & $27^{\prime \prime}$ & 20 & 25 & $2,22 "$ \\
\hline 12 & R27 & $7,0 "$ & $20 "$ & 15 & 25 & 2,20 \\
\hline 13 & R28 & $6,5^{\prime \prime}$ & $20 "$ & 21 & 32 & $2,15^{\prime \prime}$ \\
\hline 14 & R29 & $6.8^{\prime \prime}$ & $23^{\prime \prime}$ & 20 & 27 & 2,20 \\
\hline 15 & R30 & $7,5^{\prime \prime}$ & $25^{\prime \prime}$ & 18 & 24 & $2,15^{\prime \prime}$ \\
\hline
\end{tabular}

Tabel 4. Norma Hasil Tes Tingkat Kesegaran Jasmani Siswa yang Tinggal di Daerah Pesisir

\begin{tabular}{ccccccccc}
\hline No & Nama & $\begin{array}{c}\text { Lari } \\
40 \\
\text { Meter }\end{array}$ & $\begin{array}{c}\text { Gantung } \\
\text { Siku } \\
\text { Tekuk }\end{array}$ & $\begin{array}{c}\text { Baring } \\
\text { Duduk }\end{array}$ & $\begin{array}{c}\text { Loncat } \\
\text { Tegak }\end{array}$ & $\begin{array}{c}\text { Lari } \\
600 \\
\text { Meter }\end{array}$ & $\begin{array}{c}\text { 灵 } \\
\text { Kategori }\end{array}$ & \\
\hline 1 & R16 & 4 & 2 & 4 & 3 & 2 & 15 & Sedang \\
\hline 2 & R17 & 4 & 3 & 4 & 3 & 3 & 16 & Sedang \\
\hline 3 & R18 & 4 & 3 & 4 & 2 & 4 & 17 & Sedang \\
\hline 4 & R19 & 3 & 4 & 4 & 4 & 3 & 18 & Baik \\
\hline 5 & R20 & 3 & 3 & 3 & 2 & 4 & 15 & Sedang \\
\hline 6 & R21 & 4 & 3 & 4 & 2 & 4 & 17 & Sedang \\
\hline 7 & R22 & 4 & 3 & 5 & 2 & 4 & 18 & Baik \\
\hline 8 & R23 & 3 & 4 & 3 & 2 & 4 & 16 & Sedang \\
\hline 9 & R24 & 4 & 1 & 3 & 2 & 3 & 13 & Kurang \\
\hline 10 & R25 & 3 & 3 & 3 & 2 & 4 & 15 & Sedang \\
\hline 11 & R26 & 4 & 3 & 4 & 2 & 4 & 17 & Sedang \\
\hline 12 & R27 & 3 & 3 & 3 & 2 & 4 & 15 & Sedang \\
\hline 13 & R28 & 4 & 3 & 4 & 3 & 4 & 18 & Baik \\
\hline 14 & R29 & 4 & 3 & 4 & 2 & 4 & 17 & Sedang \\
\hline 15 & R30 & 3 & 3 & 4 & 2 & 4 & 16 & Sedang \\
\hline
\end{tabular}

Tabel 5. Distribusi Frekuensi Tingkat Kesegaran Jasmani Siswa yang Tinggal di daerah Pegunungan 


\begin{tabular}{lccc}
\hline Kriteria & Interval Prosentase & Jumlah Siswa & Prosentase (\%) \\
\hline Baik Sekali & $22-25$ & 1 & 6,6 \\
Baik & $18-21$ & 10 & 66,6 \\
Sedang & $14-17$ & 3 & 20 \\
Kurang & $10-13$ & 1 & 6,6 \\
Kurang Sekali & $5-9$ & 0 & 0 \\
& & & \\
\hline Jumlah & & 15 \\
\hline
\end{tabular}

Tabel 6. Distribusi Frekuensi Tingkat Kesegaran Jasmani Siswa yang Tinggal di Daerah Pesisir

\begin{tabular}{lccc}
\hline Kriteria & $\begin{array}{c}\text { Interval } \\
\text { Prosentase }\end{array}$ & $\begin{array}{c}\text { Jumlah } \\
\text { Siswa }\end{array}$ & $\begin{array}{c}\text { Prosentase } \\
(\%)\end{array}$ \\
\hline Baik Sekali & $22-25$ & 0 & 0 \\
Baik & $18-21$ & 3 & 20 \\
Sedang & $14-17$ & 11 & 73,3 \\
Kurang & $10-13$ & 1 & 6,6 \\
Kurang Sekali & $5-9$ & 0 & 0
\end{tabular}

Jumlah

15

\section{Pembahasan}

Berdasarkan hasil analisis data menunjukkan bahwa tingkat kesegaran jasmani siswa yang tinggal di daerah pegunungan 1 orang atau $6,6 \%$ menunjukkan kriteria baik sekali , kemudian 10 orang atau $66,6 \%$ menunjukkan kriteria baik, 3 orang atau $20 \%$ menunjukkan kriteria sedang 1 orang atau $6,6 \%$ menunjukkan kriteria kurang, namun tidak ada yang termasuk kriteria kurang sekali.

Tingkat kesegaran jasmani siswa yang tinggal di daerah pesisir tidak ada siswa yang menunjukkan kriteria baik sekali, kemudian 3 orang atau 20\% menunjukkan kriteria baik, 11 orang atau $73,3 \%$ menunjukkan kriteria sedang 1 orang atau $6,6 \%$ menunjukkan kriteria kurang, namun tidak ada yang termasuk kriteria kurang sekali.

Dari data di atas menunjukkan bahwa tingkat kesegaran jasmani siswa yang tinggal di daerah pegunungan mempunyai tingkat kesegaran jasmani yang lebih baik dibandingkan tingkat kesegaran jasmani siswa yang tinggal di daerah pesisir. Kondisi ini sesuai karena siswa yang tinggal di daerah pegunungan dalam keseharian banyak menggunakan aktivitas fisik mulai dari kegiatan pada saat berangkat ke sekolah dengan berjalan kaki begitu juga sebaliknya pada saat pulang dari sekolah dengan berjalan kaki, ditambah dengan kegiatan-kegiatan lain seperti membantu orang tua di kebun. Sedangkan siswa yang tinggal di daerah pesisir aktivitas keseharian kurang mengunakan kegiatan fisik, karena banyak bantuan dari fasilitas pendukung seperti pada saat berangkat ke sekolah dengan menggunakan motor begitu juga dengan aktivitas lainnya.

Kegiatan yang banyak menggunakan aktivitas fisik akan memiliki otot yang kuat, otot yang harus bekerja lebih keras pada saat berjalan kaki adalah seluruh otot kaki dari betis ke persendian di pangkal paha. Juga menggunakan otot bagian atas yaitu otot di bagian punggung dan pundak dikarenakan ayunan tangan. Hal ini sesuai dengan pendapat Sumosardjono (1996:8) sembilan keuntungan setelah berlatih gerak jalan secara bertahap, teratur dan cukup lama:

a. Dengan jalan kaki secara bertahap, teratur, dan cukup lama maka jumlah dan besarnya pembuluh darah kita akan bertambah sehingga peredaran darah kita menjadi lebih efisien.

b. Dengan jalan kaki akan menaikkan elastisitas pembuluh darah hingga dapat mengurangi kemungkinan pecahnya pembuluh itu jika tekanan darah kita naik.

c. Otot-otot dan peredaran darah kita akan bekerja lebih efisien yang berarti otot dan darah kita akan lebih sempurna mengambil, mengedarkan dan menggunakan oksigen.

d. Jantung kita akan mendapat keuntungan karena juga bekerja lebih efisien yaitu memompa darah lebih banyak dengan denyutan lebih jarang, serta akan lebih tahan terhadap kemungkinan serangan penyakit jantung.

e. Bertambah kuatnya ketahanan kita terhadap stress. 
f. Dapat menurunkan kadar lemak dalam darah.

g. Mengurangi terjadinya penggumpalan darah sehingga kemungkinan tersumbatnya pembuluh darah yang menuju otot jantung akan berkurang.

h. Kadar gula darah juga akan turun sehingga mengurangi kemungkinan perubahan gula darah menjadi lemak.

i. Dapat mengurangi kegemukan dan tekanan darah tinggi.

Berdasarkan dari pendaapat tersebut mendukung tentang perlunya aktivitas fisik dalam kegiatan keseharian agar kesegaran jasmani dapat meningkat. Hal ini juga terbukti pada siswa SDN 46 Kota Parepare dengan hasil tingkat kesegaran jasmani siswa yang tinggal di pegunungan lebih baik dari pada siswa yang tinggal di daerah pesisir.

\section{KESIMPULAN \& SARAN}

Berdasarkan data yang diperoleh dalam penelitian ini dapat disimpulkan bahwa siswa yang tinggal di daerah pegunungan lebih baik tingkat kesegaran jasmaninya dibandingkan dengan siswa yang tinggal di daerah pesisir. Siswa yang yang tinggal di daerah pegunungan yang mempunyai tingkat kesegaran jasmani "kategori baik" lebih banyak prosentasenya. Hal ini karena siswa tersebut lebih banyak menggunakan aktifitas fisik dalam kegiatan keseharian dibandingkan dengan siswa yang tinggal di daerah pesisir lebih banyak menggatungkan aktivitasnya dengan bantuan alat atau mesin sehingga kegiatan fisiknya dapat dikatakan sangat kurang.

Berdasarkan kesimpulan, maka peneliti memberikan saran-saran sebagai berikut:

1. Pihak sekolah harus memperhatikan dan berusaha meningkatkan pada pembinaan dan peningkata kesegaran jasmani para siswa

2. Untuk para siswa hendaknya meningkatkan kesegaran jasmani dengan senantiasa melakukan aktifitas-aktifitas fisik dan tidak terlalu menggantungkan pada alat atau mesin sehingga melupakan aktifitas fisik.

3. Guru pendidikan jasmani hendaknya lebih memotivasi dan berusaha meningkatkan kesegaran jasmani anak didiknya dengan kegiatan olahraga.

\section{DAFTAR PUSTAKA}

Aderson 1961. Measurement In Physical Education. WB- Saunders Company, Philadelphia, London.

Amari. 1986. Tes Dan Pengukuran Dalam Bidang Olahraga. Penerbit Toko Buku Mawa, Surabaya.

Arikunto, Suharsimi. 1996. Prosedur Penelitian Suatu Pendekatan Praktek. Penerbit PT. Rineka Cipta, Jakarta.

Depdikbud. 2000. Tes Kesegaran Jasmani Indonesia (TKJI). Pusat Kesegaran Jasmani dan Rekreasi, Jakarta.

Hadi, Sutrisno. 1990. Analisis Regresi. Penerbit Andi offset, Yokyakarta.

Kosasi, Engkos. 1993. Anak dan Perkambangannya. PT. Gramedia, Yogyakarta.

Kusuma, Dede. 1989. Olahraga dan Manfaatnya. Penerbit CV. Karya Ilmu, Jakarta.

Lisnawati. 1996. Studi perbandingan kemampuan aerobik antar murid sekolah dasar daerah perkotaan dengan pedesaan di Kabupaten Polmas. Skripsi, FIK UNM Makassar.

Menegpora. 1999. Kesegaran Jasmani Bangsa. Proyek Pendidikan Olahraga, Jakarta.

Narbuko, Cholik. 2004. Metodologi Penelitian. Bumi Aksara: Jakarta.

Pasau, Anwar, M. 1984. Pertumbuhan Dan Perkembangan Fisik. FPOK IKIP Ujung Pandang.

Said, Nurhasan. 1992. Evaluasi Pengajaran Kesehatan. Depdikbud

Sajoto, M. 1988. Pembinaan Kondisi Fisik dalam Olahraga. Depdikbud Dirjen Dikti, Jakarta.

Sharkey, B.J. 1984. Physiology Of Fotness. Second Edition, Champaign Human Kinetcs Publishers. 